We have seen in the preceding pages that the term "Greensand" was originally applied by Smith and Webster to the bed now known as Upper Greensand', and that, through the excusable, but most unfortunate, misconceptions of succeeding writers, it came to be applied to a formation of mush older date; also how, in an ineffectual attempt to get rid of the confusion which had arisen, the words Upper and Lower came to be added to the term. We have also seen the great objections there are to the term "Lower Greensand," and the attempts which have been made in this country to find a substitute for it. Eaistly, we have followed the labours of those geologists in Switzerland and France, who, studying the-same formation in its more complete development, have suggested a name in every respect suitable-one against which no valid objection has ever been urged, and which has taken a firm root in geological literature.

It is for these reasons that we believe that the term Neocomian. has claims before all others to be-applied to the great system of strata between the Cretaceous and the Oolites. Terms like Silurian and Neocomian are the monuments of great epochs in the history of geological discovery, and the former is not more closely associated with the achievements of Munchison than is the latter-with. the labours of de Montmollin.

\title{
NOIICES OF MTHMIIS.
}

I.-ON the Surface-Geology of the Basin of the Great liakizs,

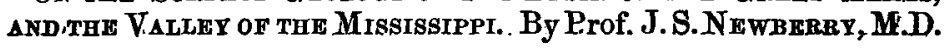

[Annals of the Lyceum of Nat. Hist.,_New York, Vol. IX., 1869.]

TWHE area under consideration is bounded: on the north by the Eozoic highlands of Canada, on the east by the Adirondacks and Alleghanies, and on the west by, the Rocky Mountains.

Marks of glacial action are abundant in the northern half of the area, and where the nature of the rocks is such as to retain inscriptions, there numerous furrows are found, having a general north and south direction.

In the southern half of the Mississippi valley the evidences of glacial action are entirely wanting, and there is nothing corresponding to the wide-spread Drift deposits of the north. The points of chief interest are the proofs which it furnishes of erosion on a stupendous scale.

Some of the valleys and channels. (in the northern area) which bear the marks of glacial action-evidently: formed or modified by ice, and dating from the Glacial period or an earlier epoch-are excavated far below the present lakes and water-courses which occupy them. These valleys form a connected system of drainage, at a lower level than the present river system.

Lakes Michigan, Huron, Erie, and Ontario, are basins excomated in undisturbed sedimentary rocks. An old excavated, but: now filled up channel connects Lakes Erie and Huron. Another trough runs 
south from Lake Michigan-filled with clay, sand, trunks of trees, etc.- which has been penetrated in one place to a depth of 230 feet.

The borings for oil in the valleys of the Western rivers have enabled Professor Newberry not only to demonstrate the existence of deeply buried ehannels of excavation, but in many cases to map them out. He points out the importance of a knowledge of these old channels in the improvement of the navigation of our larger rivers, as this may in many cases prove valuable in constructing canals, when millions of dollars might be expeaded in rock excavation.

Upon the glaciated surfaces of the solid rocks are found series of unconsolidated materials, generally stratified. These are the Drift deposits, which occur in the following (ascending) order:-

1. The Erie clays of Sir W. E. Logan. They consist of blue and red clays, finely stratified, with drifted coniferous wood and leaves, and containing in some places beds of gravel and boulders. In Ohio these clays are nearly 200 feet in thickness. They fill the old channel which formerly connected lakes Erie and Huron; here they are over 200 feet thick.

2. Above the Erie clays are Sands of variable thickness, less widely spread than the clays. They contain beds of gravel, and near the surface water-wom teeth of Elephants have been found.

3. Upon these clays, sands, and gravels, are scattered boulders of all sizes, composed of granite, diorite, and dolerite, mica-slate, etc., generally traceable to the Eozoic area north of the lakes. There are also many balls of native eopper from the copper district of Lake Superior.

Above all these Drifts, and more recent than any of them, are " lake-ridges," embankments of sand, gravel, sticks, leaves, etc., which run rudely parallel to the present margin of the lakes, when highlends lie in the rear. The author regards them as true lakebeaches.

Professcr Newbenry gives some theoretical deductions regarding the history of these deposits, and then discusses the origin of the Great Lakes. Some of them are embraced in the folding of the Fozoic rooks, and fill synolinal troughs; but most of the series, from Great Bear Lake to Lake Ontario, are basins of excavation in the Palæozoie plain that flanks in a parallel belt the Laurentian area. The bottoms and sides of the lake-basins, wherever exposed to observation, if composed of resistant materials, bear indisputable evidenoe of ice-action, proving that these basins were filled by moving glaciers in the last ice-period. He considers that no other agent than glacial ice is capable of excavating broad, deep, boat-shaped basins, like those which hold the lakes. This theory, it is hardly mecossary to say, is in accordance with that which was first promulgated by Professor Ramsay, and which, although it met with disfayour when it was first started some time since (1862), has eertainly been gaining ground, though slowly, and it seems probable that the glacial origin of rock-basins occupied by lakes will ere long be generally accepted,-H. B. W. 


\section{II.-The Grological Rhuations of the Alpine flora of Grhat Britain. By the Rev. Jas. M. Crombie.}

(A paper read before the Geologists' Association of London.)

T $N$ this paper Mr. Crombie discusses the origin of the Alpine (or 1 Boreal) Flora of Great Britain, showing that it is directly due to a past geological condition of our island. This Alpine Flora is met with upon our higher mountains; but only on the higher ranges of Scotland, on the lofty and extensive Grampians, does it occur in great plenty and variety.

The limits within which the plants are usually found are from about 1,506 to 4,406 feet (the summit of Ben Nevis). This space has been divided into certain zones, both physically and botanically distinct from each other, and these are applicable to all the loftier mountains, making due allowance for diversity of situation, mineralogical structure, etc.

The flora of each is so similar in its main features as clearly to betray a common origin and a similar mode of distribution. Between our Alpine Flora and that of Scandinavia there is a great similarity, and the author considers that the boreal forms of Great Britain were derived from it.

He agrees with the late Professor Fdward Forbes that the distribution of this Alpine Flora was effected during the Glacial epoch, which, indeed, the character of the plants themselves renders most probable.

III.-Prochedings of Thi Bristol Naturalists' Sootety. Vol. IV. For the year 1869 .

TN their Report of 1869 , the Council of the Society regret to state that, although a fair amount of work has been done during the year, yet there has been but a poor attendance of members, both at the general Evening Meetings, and at the Summer Excursions. The number of members has also decreased from 215 , in 1868 , to 167 , in 1869 ; in addition to which however there are seven Lady Associates.

In the present volume there are eleven papers, including some on Geological subjects.

There is an Analysis of the Report presented by the late Prof. W. Hopkins to the British Association, "On the Theories of Elevation and Earthquakes," by the President of the Society, Mr. W. Sanders, F.R.S., etc.

The Rev. Canon Moseley, F.R.S., Vice-President, communicates a paper "On the Cause of the Descent of Glaciers."

He considers that a glacier would not by its weight descend. As glaciers move faster by day than by night, and faster in summer than in winter, he maintains that it must be the variation in the amount of solar heat which causes the changes of glacier motion.

His theory is, that dilatation and contraction of the ice, produced by the passage into it and withdrawal from it of the sun's rays, is the proximate cause of the descent of glaciers. 